\title{
Perlindungan Hak Pekerja Atas Pemutusan Hubungan Kerja Dengan Alasan Pandemi Covid-19 Berdasarkan Undang-Undang Nomor 11 Tahun 2020 Tentang Cipta Kerja
}

\author{
Nirwana Hendri Sulistyo ${ }^{1}$ dan Surahmad $^{2}$ \\ ${ }^{1,2}$ Fakultas Hukum, Universitas Pembangunan Nasional Veteran Jakarta \\ Corresponding author. Email : sulistyohendri@gmail.com
}

Naskah diterima: 25-01-2021 revisi: 10-02-2021; disetujui: 18-05-2021

DOI: https://doi.org/10.46257/jrh.v25i1.194

\begin{abstract}
Abstrak
Pandemi COVID-19 sangat berdampak terhadap banyak sektor kehidupan rakyat Indonesia, tanpa terkecuali ketenagakerjaan. Hingga Oktober 2020, pekerja yang terkena Pemutusan Hubungan Kerja (PHK) maupun dinonaktifkan dalam kurun waktu yang tidak ditentukan mencapai 6,4 juta sebagai imbas dari kerugian yang terus dialami perusahaan. Lebih buruk lagi, banyak di antara mereka yang tidak memperoleh haknya setelah mengalami PHK dengan alasan COVID-19 tersebut. Hal ini menunjukkan peraturan perundang-undangan yang selama ini berlaku tidak mampu dilaksnakan sepenuhnya. Namun, kini, telah terjadi perubahan peraturan mengenai hak pekerja ter-PHK, yakni Undang-Undang Nomor 11 Tahun 2020 Tentang Cipta Kerja yang mencabut/mengubah beberapa ketentuan dalam Undang-Undang Nomor 13 Tahun 2003 Tentang Ketenagakerjaan. Tujuan yang ingin diraih dengan adanya penelitian ini adalah untuk memperoleh hasil analisis perihal hak-hak pekerja ter-PHK dengan alasan COVID-19 menurut Undang-Undang Cipta Kerja, dan bentuk pelindungannya. Analisis dilakukan melalui metode studi kepustakaan dengan menggunakan Undang-Undang Cipta Kerja sebagai bahan analisis utama, dan ditunjuang dengan bahan hukum lain yang terkait. Penelitian ini menghasilkan kesimpulan bahwa terjadi perubahan mengenai hak-hak pekerja ter-PHK, khususnya dengan alasan COVID-19. Di samping itu, Undang-Undang Cipta Kerja juga turut memberikan pelindungan terhadap hak pekerja ter-PHK.
\end{abstract}

Kata kunci: perlindungan hukum, hak pekerja, COVID-19.

\section{Protection of Workers Rights for Termination of Employment for The Reasons of The Covid-19 Pandemic Based on Law Number 11 of 2020 Concerning Job Creation}

\begin{abstract}
The COVID-19 pandemic has had a huge influence on diverse sectors of life in Indonesian society, including labor. Until October 2020, 6.4 million workers being laid off or placed on furlough. One of the worst things, lots of them did not receive their rights after being laid off. This indicates that all this time, the law is unable to be implemented optimally. However, Law No. 11 of 2020 concerning Job Creation which change some provisions of
\end{abstract}


Law No. 13 of 2003 concerning Labor is already in effect. This research was conducted to analyze the rights of laid off workers based on Law of Work Creation, and how the protection to them. The analyze was carried out by library study using Law of Work Creation as a main object which supported by the other related law literature. The results of this research concluded that Law of Work Creation had made some changes on provisions about rights of laid off workers, especially due to COVID-19 pandemic, and has provided protection to them.

Keywords: legal protection, workers rights, COVID-19.

\section{Pendahuluan}

Warga negara Indonesia seyogyanya dapat hidup dengan makmur di atas tanah air sendiri, sehingga kebutuhan hidup yang bersifat dasar seperti sandang, pangan, dan papan dapat terpenuhi. Di samping itu, masih terdapat kebutuhan lain yang kedudukannya tidak kalah penting bagi kehidupan setiap warga negara, salah satunya adalah pekerjaan. Hal ini tertera di dalam Pasal 27 ayat (2) Undang-Undang Dasar Negara Republik Indonesia 1945 (selanjutnya disebut UUD 1945). Pasal tersebut menjamin bahwa tiap-tiap warga negara berhak atas pekerjaan dan penghidupan yang layak bagi kemanusiaan.

Realitanya, pelaksanaan Pasal 27 UUD 1945 tidak bisa selalu diterapkan dengan maksimal. Begitu banyak tenaga kerja Indonesia yang belum terserap dengan kondisi peluang kerja yang ada. Hal tersebut dapat dibuktikan melalui data yang dihimpun oleh Badan Pusat Statistik (BPS). BPS menyatakan, hingga Februari 2020, angka penganggur mencapai 6,88 juta dari 137,91 juta orang angkatan kerja (Badan Pusat Statistik, 2020).

Dunia ketenegakerjaan tidak pernah luput dari permasalahan, mulai dari terbatasnya lapangan kerja yang memadai, hingga sering terjadinya pemutusan hubungan kerja (PHK). PHK bukanlah sesuatu yang dilarang dalam Peraturan Perundang-undangan. Pasal 151 ayat (2) Undang-Undang No. 13 Tahun 2003 Tentang Ketenagakerjaan menyatakan, jika di suatu perusahaan terdapat perselisihan hubungan industrial melibatkan pengusaha dan buruh yang tidak terselesaikan dengan berbagai upaya yang telah ditempuh, PHK dapat dilakukan melalui perundingan antara para pihak. Namun, jika PHK dilakukan terhadap 
pekerja dalam angka yang besar dan dalam tenggang waktu yang berdekatan, hal tersebut akan sangat memengaruhi kesejahteraan hidup banyak orang, sehingga bertentangan dengan Pasal 27 UUD 1945. Terlebih, PHK kian marak terjadi beberapa bulan belakangan ini. Hal tersebut disebabkan adanya fenomena mewabahnya virus Corona, atau World Health Organization (WHO) menyebutnya dengan Coronavirus Disease 2019 (COVID-19) (Nugroho, 2020).

Dunia pada saat ini, termasuk Indonesia sedang berjuang menanggulangi penyebaran wabah COVID-19. Isu menyebarnya virus ini dipertegas oleh Presiden Republik Indonesia Joko Widodo, melalui Keppres No. 12 Tahun 2020 Tentang Penetapan Bencana Nonalam Penyebaran Corona Virus Disease 2019 (COVID-19) Sebagai Bencana Nasional, yang ditetapkan tepat pada tanggal 13 April 2020. Dalam upaya penyusunan strategi untuk menanggulangi wabah ini, Pemerintah Indonesia mengambil kebijakan untuk menginstruksikan berbagai instansi pemerintahan atau swasta untuk memberlakukan sistem kerja dari rumah (Work From Home/WFH). Dengan kata lain, tidak berkegiatan di area kantor. WFH merupakan bentuk ikhtiar menekan laju penyebaran COVID-19, sebagaimana diatur dalam Keputusan Menteri Kesehatan Republik Indonesia Nomor Hk.01.07/Menkes/413/2020 Tentang Pedoman Pencegahan Dan Pengendalian Coronavirus Disease 2019 (COVID-19).

Situasi macam ini membuat perputaran uang pada perusahaan tidak bisa berjalan seperti biasanya karena sedikit-banyak akan menghambat proses produksi (Randi, 2020:23). Salah satu hal sangat berpotensi terjadi akibat hal tersebut adalah perusahaan tidak dapat lagi memenuhi kewajiban untuk memberi upah para pekerjanya karena terus mengalami kerugian sehingga akan berujung pada PHK yang mana merupakan jalan terakhir untuk memangkas pengeluaran.

Merujuk kepada data yang dimiliki oleh Kamar Dagang dan Industri Indonesia (Kadin) hingga Oktober 2020, jumlah pekerja (formal maupun informal) yang mengalami PHK maupun dirumahkan sebagai imbas dari pandemi COVID-19 mencapai lebih dari 6,4 juta orang (Kurniati, 2020). Angka ini sangatlah besar, mengingat kasus COVID-19 di Indonesia baru muncul sekitar awal Maret 2020. Tentu saja ini merupakan pukulan telak bagi dunia 
ketenagakerjaan Indonesia. Dengan angka PHK yang begitu besar dan berpotensi terus meingkat karena tidak ada kepastian kapan wabah ini akan berakhir, tentu permasalahan pemenuhan hak pekerja ter-PHK oleh pengusaha akan semakin banyak, dan semakin rawan terjadi ketidakselarasan antara das sollen dan das sein.

Salah satu bentuk nyata PHK yang terjadi dengan alasan pandemi COVID19 adalah kejadian yang dialami Mansyurruman, seseorang yang bekerja di suatu pabrik mesin industri dan konstruksi di Sidoarjo, Jawa Timur. Sebagaimana dilansir BBC News Indonesia pada 30 April 2020, Mansyurruman di-PHK akibat pabrik tempat ia bekerja mengalami kerugian sebagai imbas dari pandemi COVID-19, pada awal April 2020. Hal yang menambah keprihatinan adalah ia tidak menerima hak yang seharusnya diperoleh buntut dari PHK tersebut. Ia telah bekerja selama 13 (tiga belas) tahun, dan jika dihitung, jumlah pesangon dan hak-hak lainnya mencapai angka Rp. 107.000.000,00 (Yuniar, 2020). Peristiwa ini menunjukkan bahwa pada saat itu, ketentuan UndangUndang Ketenagakerjaan belum bisa dilaksanakan dengan maksimal.

Namun, berbicara mengenai pengaturan hak pekerja ter-PHK, kini mengacu pada Undang-Undang yang baru berlaku setelah dibubuhi tanda tangan oleh Presiden Joko Widodo, tepat pada 2 November 2020, yaitu Undang-Undang No. 11 Tahun 2020 Tentang Cipta Kerja. Undang-Undang ini dibentuk dengan tujuan merampingkan regulasi yang sudah terlalu bertumpang tindih dengan cara mencabut beberapa aturan yang sebelumnya ada dalam beragam UndangUndang sekaligus, atau dikenal dengan metode omnibus law. Undang-Undang Cipta Kerja berisikan 10 (sepuluh) klaster, dan salah satunya adalah Ketenagakerjaan. Berbagai ketentuan mengenai PHK telah diubah/dicabut dari Undang-Undang Ketenagakerjaan, termasuk di dalamnya hak pekerja ter-PHK.

Undang-Undang Cipta Kerja harus dianalisis secara mendalam, khususnya mengenai pelindungan terhadap hak pekerja ter-PHK dengan alasan pandemi COVID-19. Jika Undang-Undang Cipta Kerja tidak memberikan pembaruan yang signifikan, angka pekerja yang tidak memperoleh hak setelah di-PHK dengan alasan pandemi ini akan terus membengkak. 
Urgensi akan pelindungan tersebut yang menggugah keinginan peneliti untuk membuat penelitian ini. Pokok permasalahan yang akan dipecahkan dalam penelitian ini, yaitu:

a. Bagaimanakah ketentuan hak pekerja atas pemutusan hubungan kerja dengan alasan pandemi COVID-19 setelah disahkannya Undang-Undang No. 11 Tahun 2020 Tentang Cipta Kerja?

b. Apa sajakah jenis pelindungan hak pekerja atas pemutusan hubungan kerja dengan alasan pandemi COVID-19 dalam Undang-Undang No. 11 Tahun 2020 Tentang Cipta Kerja?

Penelitian hukum ini termasuk dalam kategori penelitian hukum/yuridis normatif atau biasa disebut penelitian hukum doktrinal (Ali, 2017:24), yaitu jenis penelitian yang memaksimalkan sumber data sekunder dengan menitikberatkan pada studi dokumen berupa surat pribadi, buku/penelitian hingga pada dokumen resmi yang dikeluarkan oleh lembaga Negara yang pada penelitian ini ditujukan untuk mengumpulkan data mengenai pelindungan hukum terhadap hak-hak pekerja ter-PHK dengan alasan wabah COVID-19 berdasarkan Undang-Undang No. 11 Tahun 2020 Tentang Cipta Kerja.

Pendekatan masalah yang digunakan, yaitu pendekatan perundangundangan (Statute Approach). Pendekatan ini digunakan untuk menganalisis peraturan perundang-undangan yang menimbulkan ketidakselarasan antara norma dan pelaksanaannya di lapangan (Sunggono, 2018).

Data dari penelitian dihasilkan melalui rentetan studi kepustakaan (Library Research), sehingga diperoleh bahan hukum primer, sekunder, dan tersier yang saling menunjang satu sama lain. Seluruh data yang didapat langsung diolah menggunakan teknik deskripsi kualitatif, yaitu pemanfaatan data kualitatif yang dijelaskan secara deskriptif untuk menemukan pemecahan dari permasalahan menjadi inti dari penelitian ini. Teknik ini dilakukan dengan menyusun kalimat secara teratur, berkelanjutan, efektif, dan juga logis, sehingga membuat substansi dapat lebih mudah dipahami. 


\section{Pembahasan}

\section{A. Ketentuan Hak Pekerja Atas Pemutusan Hubungan Kerja Dengan Alasan Pandemi COVID-19 Setelah Disahkannya Undang-Undang No. 11 Tahun 2020 Tentang Cipta Kerja}

Pemutusan Hubungan Kerja (PHK) dapat diartikan sebagai pengakhiran hubungan kerja antara pengusaha/perusahaan dengan pekerja/buruh yang disebabkan oleh bermacam-macam faktor penting (Simanjuntak, 2012:18). Setelah terjadinya PHK, bukan berarti hubungan antar pengusaha dengan pekerja usai begitu saja. Masih ada persoalan sebagai buntut dari PHK tersebut, salah satunya adalah pemenuhan hak pekerja ter-PHK oleh pengusaha.

Pada saat pandemi COVID-19 sekarang ini, perusahaan terus mengalami kerugian, sehingga PHK semakin tidak terhindarkan (Suwantari \& Astariyani, 2020). Tidak berhenti pada tingginya angka PHK, persoalan pemenuhan hak pekerja ter-PHK pun tidak kunjung surut. Banyaknya persoalan ketenagaekerjaan tersebut yang menjadi dasar Pemerintah bersama DPR membentuk Undang-Undang No. 11 Tahun 2020 Tentang Cipta Kerja, dengan harapan mampu dijadikan solusi jangka panjang. Meskipun begitu, sejumlah aturan dalam Undang-Undang Ketenagakerjaan masih berlaku, karena UndangUndang Cipta Kerja tidak mencabut keseluruhan Undang-Undang Ketenagakerjaan. Hal tersebut dijelaskan dalam Pasal 80 Undang-Undang Cipta Kerja yang intinya menyatakan bahwa telah dilakukan pengubahan, penghapusan, atau penetapan aturan baru terhadap beragam ketentuan yang berasal dari beberapa Undang-Undang terkait, salah satunya Undang-Undang Ketenagakerjaan, dengan tujuan peningkatan perlindungan terhadap tenaga kerja, menguatkan peran, serta kesejahteraan tenaga kerja sebagai bentuk dukungan terhadap ekosistem investasi. Maka, aturan-aturan yang tidak diubah/dicabut masih berlaku dan mengikat.

Sebelum mengulas mengenai hak pekerja ter-PHK dengan alasan pandemi COVID-19 dalam Undang-Undang Cipta Kerja, akan lebih dahulu dilakukan penjelasan mengenai dua jenis perjanjian kerja yang mengikat pihak pengusaha dan pekerja, alasannya adalah tiap-tiap jenis perjanjian kerja menciptakan 
keadaan hukum yang berbeda dalam hal terjadi PHK. Di Indonesia, dikenal ada dua bentuk perjanjian kerja, yaitu Perjanjian Kerja Waktu Tertentu (PKWT) dan Perjanjian Kerja Waktu Tidak Tertentu (PKWTT).

Pengertian tentang PKWT dapat ditemukan dalam Pasal 80 angka 15 Undang-Undang Cipta Kerja yang mengubah ketentuan Pasal 59 UndangUndang Ketenagakerjaan. Berdasarkan pasal tersebut, PKWT diartikan sebagai perjanjian kerja yang dibuat hanya untuk pekerjaan tertentu, yang dapat dilihat berdasarkan jenis, sifat, atau kegiatan pekerjaannya yang hendak selesai dalam waktu menurut kesepakatan para pihak nanti. Selain itu, PKWT juga dapat diartikan sebagai perjanjian kerja yang dibentuk cuma untuk pekerjaan yang sifatnya sementara/musiman dan dapat diperkirakan rampung dalam hitungan waktu yang tidak begitu lama. Pekerja yang terikat dalam PKWT sering disebut dengan pekerja tidak tetap.

Pengertian mengenai PKWTT tidak tertulis begitu detail, baik dalam Undang-Undang Ketenagkerjaan, maupun Undang-Undang Cipta Kerja. Berdasarkan pengertian tentang PKWT, PKWTT dapat diartikan secara berlawanan. Jadi, PKWTT merupakan perjanjian kerja yang dapat dibuat untuk pekerjaan yang tidak terbatas pada jenis, sifat, maupun kegiatan pekerjaannya yang bersifat sementara, atau akan rampung dalam waktu tertentu. Dengan kata lain, PKWTT dibuat untuk mengikat pengusaha dan pekerja dalam hal pekerjaan yang bersifat tetap. Pekerja yang terikat dalam PKWTT sering disebut dengan pekerja tetap.

Selanjutnya, perlu dibahas juga mengenai pengklasifikasian alasan pandemi COVID-19 untuk melaksanakan PHK menurut ketentuan Undang-Undang. Pengaturan alasan yang dapat dipilih sebagai dasar untuk melakukan PHK terdapat dalam Pasal 81 angka 44 Undang-Undang Cipta Kerja yang menetapkan penyisipan Pasal 154A di antara Pasal 154 dan Pasal 155 UndangUndang Ketenagakerjaan. Dari banyaknya alasan yang dapat menjadi penyebab terjadinya PHK, hemat kami, alasan pandemi COVID-19 lebih relevan dimasukkan ke dalam kategori force majeure (keadaan memaksa). Keadaan memaksa dapat diartikan sebagai keadaan yang tercipta di luar kemampuan 
kendali manusia serta tidak mampu terhindarkan, hingga menyebabkan suatu kewajiban/tindakan tidak dapat dilaksanakan oleh para pihak, dalam hal ini pengusaha/perusahaan dan pekerja (Pokrol, 2003). Keadaan memaksa bisa disebabkan oleh bencana alam/non alam, dan kejadian lain di luar kuasa manusia lainnya.

Alasan pandemi COVID-19 lebih tepat diklasifikasikan sebagai keadaan memaksa, yaitu sebagaimana keputusan Presiden Joko Widodo yang menyatakan bahwa pandemi ini termasuk ke dalam musibah non alam berskala nasional melalui Keppres No. 12 Tahun 2020. Musibah/bencana nasional ini mengakibatkan dampak yang begitu luar biasa terhadap berbagai sektor kehidupan manusia, termasuk ketenagakerjaan. Banyak perusahaan yang mengalami kerugian secara signifikan, sehingga tidak dapat menunaikan kewajiban memenuhi hak-hak pekerjanya, dan PHK pun tidak dapat lagi terhindarkan. Pengklasifikasian alasan PHK ini sangat penting dilakukan, karena di dalam Undang-Undang Ketenagakerjaan terdapat perbedaan besaran nilai hak di antara alasan-alasan dasar untuk melakukan PHK. Lantas, bagaimana dengan Undang-Undang Cipta Kerja? Apakah tetap mengadopsi ketentuan UndangUndang Ketenagakerjaan? Hal ini yang akan diulas selanjutnya.

Bagi pekerja ter-PHK atas alasan keadaan memaksa, Undang-Undang Ketenagakerjaan menentukan hak yang harus dipenuhi berupa pesangon sebesar 1 (satu) kali ketentuan Pasal 156 ayat (2), uang penghargaan masa kerja sebesar 1 (satu) kali ketentuan Pasal 156 ayat (3), dan uang penggantian hak yang mengacu pada Pasal 156 ayat (4), ketentuan tersebut mengacu kepada Pasal 164 ayat (1).

Undang-Undang Cipta Kerja mengatur mengenai alasan-alasan dasar melakukan PHK di dalam Pasal 81 angka 42, termasuk keadaan memaksa di dalamnya. Perlu diketahui juga, Pasal 161-169 Undang-Undang Ketenagakerjaan yang mengatur mengenai mekanisme penghitungan hak dari masing-masing alasan dasar PHK, dihapus. Hal ini menyebabkan tidak ada perbedaan lagi mengenai mekanisme penghitungan dari masing-masing alasan PHK. Menurut Pasal 81 angka 44 Undang-Undang Cipta Kerja, apa pun alasan 
dasar dilakukannya PHK sebagaimana diatur dalam Pasal 81 angka 42, mekanisme penghitungan besaran pesangon, uang penghargaan masa kerja, dan uang penggantian hak adalah sama, yaitu 1 (satu) kali ketentuan Pasal 156 Undang-Undang Ketenagakerjaan yang masih berlaku.

Perubahan ketentuan sebagaimana yang telah disebut sebelumnya hanya berdampak terhadap pekerja tetap, tidak berlaku untuk pekerja tidak tetap. Karena dalam Pasal 62 Undang-Undang Ketenagakerjaan dijelaskan, bagi pekerja tidak tetap yang di-PHK sebelum jangka waktu yang ditetapkan dalam PKWT berakhir, maka ia berhak atas kompensasi sebesar upahnya ketika masih aktif bekerja, sampai batas jangka waktu perjanjian kerja tersebut berakhir. Hal ini juga berlaku bagi PHK dengan alasan pandemi COVID-19 sebelum jangka waktu yang diatur dalam PKWT berakhir. Karena dalam PKWT tidak terdapat aturan mengenai pengklasifikasian alasan-alasan PHK yang dapat dilakukan, sebagaimana yang ada dalam aturan PHK terhadap pekerja tetap/PKWTT. Pasal 62 Undang-Undang Ketenagakerjaan ini tetap memiliki kekuatan hukum yang mengikat, karena tidak diubah/dicabut dalam Undang-Undang Cipta Kerja.

Selain menghapus dan mengubah beberapa ketentuan dari Undang-Undang Ketenagerkajaan yang berkaitan dengan hak pekerja ter-PHK, Undang-Undang Cipta Kerja juga turut menciptakan hal baru dalam klaster Ketenagakerjaan, yakni adanya Jaminan Kehilangan Pekerjaan (JKP). JKP termasuk dalam program jaminan sosial yang disebutkan pada Pasal 82 angka 1 Undang-Undang Cipta Kerja yang mengubah ketentuan Pasal 18 Undang-Undang Nomor 40 Tahun 2004 Tentang Sistem Jaminan Sosial Nasional. Program Jaminan ini, nantinya akan dikelola oleh Badan Penyelenggara Jaminan Sosial (BPJS) Ketenagakerjaan beserta Pemerintah Pusat berdasarkan prinsip asuransi nasional. Program ini bertujuan mempertahankan derajat kelayakan hidup bagi pekerja yang mengalami PHK, melalui pemberian uang tunai, akses atas informasi pasar kerja, serta berbagai pelatihan kerja yang dapat diikuti. Menurut Pasal 46E Bagian Ketujuh, pendanaan program ini akan bersumber dari modal awal pemerintah, rekomposisi urunan program jaminan sosial, dan uang operasional BPJS Ketenegakerjaan. Jumlah nilai maksimal dari manfaat- 
manfaat tersebut paling banyak adalah 6 (enam) bulan upah, dengan masa kepesertaan tertentu yang nantinya akan diatur rinci dalam Peraturan Pemerintah.

Dalam hal kepesertaan program Jaminan Kehilangan Pekerjaan, UndangUndang Cipta Kerja tidak mengubah/mencabut ketentuan yang lama, sehingga Pasal 13 Undang-Undang Sistem Jaminan Sosial Nasional masih berlaku dan mengikat. Dalam ayat (1) disebutkan, pemberi kerja memiliki tanggung jawab untuk mempesertakan dirinya dan juga para pekerjanya kepada BPJS secara bertahap, hal ini disesuaikan dengan progam jaminan sosial yang nantinya akan diikuti (Disantara, 2020). Dengan melihat isi dari pasal tersebut, dapat dikatakan bahwa pekerja yang berhak mengikuti program Jaminan Kehilangan Pekerjaan bukan hanya pekerja tetap, pekerja tidak tetap pun berhak turut serta. Dengan demikian, seluruh pekerja ter-PHK yang terdaftar dalam program Jaminan Kehilangan Pekerjaan dapat menikmati manfaat yang diberikan Undang-Undang Cipta Kerja.

\section{B. Jenis Pelindungan Hak Pekerja Atas Pemutusan Hubungan Kerja Dengan Alasan Pandemi COVID-19 Dalam Undang-Undang No. 11 Tahun 2020 Tentang Cipta Kerja}

Setelah Undang-Undang Cipta Kerja diketahui membuat beberapa perubahan ketentuan mengenai hak-hak pekerja ter-PHK, khususnya yang disebabkan oleh pandemi COVID-19 sebagaimana menjadi topik utama penelitian ini, selanjutnya perlu dianalisis mengenai kemampuan UndangUndang Cipta Kerja untuk dijadikan perlindungan hukum terhadap hak-hak tersebut. Namun, sebelum melaju lebih lanjut, perlu diketahui definisi dari perlindungan hukum itu sendiri. Satjipto Rahardjo mengartikan Perlindungan hukum sebagai pemberian ayoman kepada Hak Asasi Manusia (HAM) yang telah dirugikan pihak lain, dan perlindungan itu diberikan terhadap masyarakat supaya mereka mampu menikmati hak-hak yang diberikan oleh hukum (Rahardjo, 2000:54). Secara kebahasaan, perlindungan lebih tepat diartikan sebagai tempat berlindung, sedangkan pelindungan lebih tepat diartikan sebagai 
upaya melindungi. Maka, untuk selanjutnya akan menggunakan kata pelindungan untuk membahas mengenai jenis upaya melindungi (Puluhulawa, Towadi, \& Swarianata, 2020).

Pelindungan hukum dapat dikelompokkan ke dalam dua jenis, yaitu pelindungan hukum yang bersifat preventif dan pelindungan hukum yang bersifat represif (Asri, 2018:16). Pelindungan hukum preventif adalah Pelindungan yang dilakukan oleh penguasa/pemerintah untuk mencegah terjadinya pelanggaran. Hal ini dapat dilakukan dengan menetapkan batasan bagi subjek hukum dalam bertindak atau melakukan suatu perbuatan yang nantinya akan dituang dalam peraturan perundang-undangan, sehingga bersifat mengikat. Perlindungan hukum preventif dapat dilakukan dengan menetapkan sanksi yang mengikat bagi para subjek hukum, sehingga akan menciptakan kehati-hatian dalam berbuat sesuatu. Pelindungan hukum represif merupakan upaya terakhir dalam menegakkan hukum, yaitu mengaplikasikan sanksi yang telah dimuat di dalam peraturan-perundang-undangan untuk menindak tegas para pelanggar hukum. Sanksi dapat berupa penjara, denda, serta hukuman tambahan. Fungsi dari sanksi ini adalah memberikan efek jera, agar tidak terulang pelanggaran yang sama, baik oleh pelanggar yang sama, atau pihak lain. Upaya perlindungan hukum dilakukan demi merealisasikan tujuan dari hukum itu sendiri (Malau, 2013).

Meskipun perubahan mengenai hak-hak pekerja ter-PHK dalam UndangUndang Cipta Kerja banyak menuai polemik di tengah masyarakat luas, khususnya dari kalangan buruh, tetapi perlu ditelusuri lebih dalam mengenai pelindungan yang diberikan Undang-Undang ini terhadap hak-hak pekerjat erPHK.

Setelah ditelusuri, terdapat dua jenis sanksi yang bisa diberikan kepada pelanggar berbagai ketentuan dalam klaster Ketenagakerjaan Undang-Undang Cipta Kerja, yaitu sanksi administratif dan sanksi pidana. Sanksi administratif adalah sanksi yang bisa dikenakan apabila terjadi pelanggaran terhadap suatu yang sifatnya administrasi. Sanksi dapat berbentuk teguran, peringatan tertulis, pembekuan kegiatan usaha dan lain sebagainya. Sanksi Pidana merupakan 
sanksi yang berupa penjatuhan pidana terhadap pelanggaran terhadap regulasi yang berisikan norma perintah atau larangan. Berdasarkan Pasal 10 Kitab Undang-Undang Hukum Pidana (KUHP), sanksi pidana dapat berupa hukuman mati, hukuman penjara, hukuman kurungan, hukuman denda, dan hukuman tambahan lainnya (Moeljatno, 2014:5).

Sanksi administratif dapat dikenakan kepada pengusaha yang tidak membayarkan uang kompensasi kepada pekerja tidak tetap/PKWT yang terPHK. Hal ini tertuang pada Pasal 81 angka 67 Undang-Undang Cipta Kerja yang mengubah Pasal 190 Undang-Undang Ketenagakerjaan. Pasal tersebut menyatakan bahwa Pemerintah Pusat atau Pemerintah Daerah berwenang mengganjar sanksi administratif terhadap pelanggaran atas beberapa aturan, salah satunya Pasal 61A yang diselipkan di antara Pasal 61 dan Pasal 62 yang berisikan kewajiban pengusaha memberikan uang kompensasi kepada pekerja tidak tetap/PKWT yang mengalami PHK, besarannya akan disesuaikan dengan tenggang waktu kerja pekerja/buruh tersebut di tempat mereka bekerja.

Undang-Undang Cipta Kerja telah menetapkan sanksi pidana kepada pengusaha yang tidak membayarkan hak-hak pekerja (tetap/PKWTT) ter-PHK. Hak-hak tersebut meliputi uang pesangon dan/atau uang penghargaan masa kerja, dan uang sebagai penggantian hak yang belum dinikmati pekerja sebelumnya. Alasannya adalah pembayaran hak-hak pekerja tersebut merupakan perintah yang wajib ditunaikan oleh pengusaha sebagaimana tertulis dalam Pasal 81 angka 44 Undang-Undang Cipta Kerja yang mengubah Pasal 156 UndangUndang Ketenagakerjaan.

Pasal 81 angka 63 Undang-Undang Cipta Kerja berisi perubahan dari Pasal 185 Undang-Undang Ketenagakerjaan. Intinya, bagi pengusaha yang tidak membayarkan hak-hak pekerja ter-PHK yang telah diuraikan sebelumnya, dapat dijatuhkan sanksi pidana penjara paling singkat 1 (satu) tahun dan paling lama 4 (empat) tahun, dan/atau denda paling sedikit Rp. 100.000.000,- (seratus juta rupiah, dan paling banyak Rp. 400.000.000- (empat ratus juta rupiah).

Penulis sangat mengapresiasi adanya pengaturan sanksi tersebut dalam Undang-Undang Cipta Kerja. Sanksi admnistratif dan sanksi pidana yang 
mengikat dalam Undang-Undang Cipta Kerja diharapkan lebih mampu mendorong pengusaha yang melakukan PHK untuk taat terhadap hukum, dalam hal ini kewajiban membayarkan hak-hak pekerja ter-PHK. Helbert C. Kelman menyatakan bahwa terdapat 3 (tiga) jenis ketaatan terhadap hukum (A. Ali, 2009:347), yaitu:

1. Kepatuhan bersifat compliance, yakni ketika seseorang mematuhi suatu hukum karena rasa takut terhadap sanksi yang mengancam;

2. Kepatuhan bersifat identification, yakni ketika seseorang mematuhi suatu hukum karena tidak ingin hubungan baiknya dengan pihak lain akan menjadi berantakan;

3. Kepatuhan bersifat internalization, yakni ketika seseorang mematuhi suatu hukum sebab orang itu merasa bahwa hukum tersebut memang cocok dengan nilai-nilai yang dianutnya.

Jika dikaitkan dengan teori tersebut, sanksi pidana dalam Pasal 81 angka 63 Undang-Undang Cipta Kerja akan mampu menciptakan ketaatan yang bersifat compliance. Pengusaha akan lebih menaati kewajiban membayarkan hak-hak pekerja ter-PHK karena takut akan sanksi yang tidak dapat ditemui dalam undang-undang terdahulu.

Namun, di samping ketaatan yang bersifat compliance, perubahan yang dilakukan dalam Undang-Undang Cipta Kerja juga bisa menciptakan ketaatan yang bersifat internalization. Selama ini, ketentuan hak pekerja ter-PHK yang tertuang dalam Undang-Undang Ketenagakerjaan tidak mampu diaplikasikan secara maksimal. Bukan hanya karena tidak ada sanksi yang dapat diterapkan terhadap pengusaha yang tidak melaksanakan kewajibannya, tetapi juga karena besaran nilainya yang dirasa terlalu tinggi oleh para pengusaha, sehingga mereka tidak sanggup untuk mengikuti ketentuan tersebut. Hal ini disuarakan langsung oleh Menteri Ketenagakerjaan Republik Indonesia, Ida Fauziah. Menurut pernyataannya, hanya 7\% (tujuh persen) perusahaan yang sanggup mematuhi ketentuan pesangon yang terdapat dalam Undang-Undang Ketenagkerjaan (Karunia, 2020). Maka, dengan adanya penyesuaian dalam Undang-Undang Cipta Kerja, penulis berpendapat bahwa kemungkinan para 
pengusaha untuk mengikuti ketentuan Undang-Undang dalam membayarkan hak-hak pekerja ter-PHK akan lebih besar, karena lebih ramah dengan kemampuan finansial dari pihak pengusaha, sehingga tercipta ketaatan yang bersifat internalization (Juaningsih, 2020).

Meskipun Undang-Undang Cipta Kerja telah melakukan perubahan yang signifikan, tetapi tidak dapat dipungkiri bahwa ketidaksesuaian pembayaran hak-hak pekerja ter-PHK, khususnya pada saat pandemi COVID-19 seperti sekarang akan mungkin terjadi. Maka dari itu, selain mengandalkan sanksi, Undang-Undang ini juga menjamin hak pekerja ter-PHK untuk menuntut haknya melalui pengajuan gugatan ke Pengadilan Hubungan Industrial, bukan hanya untuk pekerja tetap/PKWTT, melainkan juga berlaku bagi pekerja tidak tetap/PKWT. Sebagaimana diketahui, Undang-Undang Cipta Kerja tidak mencabut/mengubah Pasal 136 ayat (2) Undang-Undang Ketenagakerjaan yang pada intinya mengatakan apabila perselisihan yang melibatkan pihak pengusaha dan pekerja/serikat pekerja tidak mampu terselesaikan melalui musyawarah, perselisihan tersebut harus diselesaikan melalui mekanisme penyelesaian perselisihan hubungan industrial yang diatur dengan Undang-Undang, dalam hal ini Undang-Undang No. 2 Tahun 2004 tentang Penyelesaian Perselisihan Hubungan Industrial (PPHI).

Undang-Undang PPHI menentukan bahwa perselisihan mengenai hak-hak pekerja atas PHK termasuk ke dalam kategori perselisihan hak. Perselisihan hak merupakan perselisihan yang timbul sebagai imbas dari tidak dipenuhinya hak oleh salah satu atau para pihak, akibat dari adanya ketidaksesuaian antara ketentuan dan pelaksanaan peraturan perundang-undangan, perjanjian kerja, peraturan perusahaan, maupun perjanjian kerja bersama. Sebelum dilakukannya penyelesaian perselisihan melalui litigasi, wajib dilaksanakan proses perundingan bipartit dan tripartit terlebih dahulu.

Perundingan bipartit diatur lebih lanjut dalam Peraturan Menteri Tenaga Kerja Dan Transmigrasi Republik Indonesia No. PER. 31/MEN/XII/2008 tentang Pedoman Penyelesaian Perselisihan Hubungan Industrial Melalui Perundingan Bipartit. Perundingan bipartit adalah proses penyelesaian 
perselisihan hubungan industrial yang hanya melibatkan pihak pengusaha dan pekerja. Perundingan dilakukan dengan mengidentifikasi dan menginventarisasi permasalahan oleh kedua belah pihak. Dalam 30 (tiga puluh) hari, apabila tercipta kesepakatan, selanjutnya dibuat penjanjian bersama yang akan dibubuhi tanda tangan oleh kedua belah pihak, dan selanjutnya akan didaftarkan ke Pengadilan Hubungan Industrial yang terdapat di Pengadilan Negeri sesuai dengan wilayah diadakannya Perjanjian Bersama. Namun, jika tidak tercipta kesepakatan, harus terlebih dahulu diupayakan perundingan tripartit.

Perundingan tripartit adalah metode penyelesaian perselisihan hubungan industrial dengan melibatkan pihak ketiga selaku fasilitator. Berdasarkan Ketentuan Umum Undang-Undang PPHI, perundingan tripartit yang dapat ditempuh untuk persoalan perselisihan hak adalah mediasi. Pengaturan lebih lanjut mengenai mediasi dimuat dalam Peraturan Menteri Tenaga Kerja dan Transmigrasi Republik Indonesia No. 17 Tahun 2014 tentang Pengangkatan dan Pemberhentian Mediator Hubungan Industrial serta Tata Kerja Mediasi. Ketika proses mediasi berjalan, kedua belah pihak akan ditengahi/dipimpin oleh seorang mediator yang bersifat netral. Seorang mediator diberi wewenang untuk mengeluarkan anjuran tertulis atas perselisihan hak yang melibatkan pengusaha dan pekerja. Apabila para pihak menyepakati anjuran tertulis yang diberikan oleh mediator tersebut, mediator akan menuangkan kesepakatan tersebut dalam perjanjian bersama yang harus ditandatangai kedua belah pihak, dan selanjutnya akan didaftarkan pada Pengadilan Hubungan Industrial yang terdapat di Pengadilan Negeri sesuai dengan wilayah diadakannya Perjanjian Bersama untuk memperoleh akta bukti pendaftaran. Apabila para pihak menolak anjuran tertulis tersebut, mediator akan mencatatnya dalam buku registrasi perselisihan. Jangka waktu maksimal mediasi adalah 30 (tiga puluh) hari kerja terhitung mulai dari pelimpahan penyelesaian perselisihan hubungan industrial.

Setelah melewati proses perundingan bipartit dan tripartit, tetapi masih belum juga tercapai kesepakatan dalam bentuk perjanjian bersama, pihak pekerja berhak mendaftarkan gugatan ke Pengadilan Hubungan Industrial di Pengadilan Negeri yang berwenang, dengan menggunakan hukum acara perdata 
secara umum, tetapi ada juga kekhususan yang termuat dalam Undang-Undang PPHI. Jangka waktu pengajuan gugatan adalah 1 (satu) tahun semenjak diterima/diberitahukannya keputusan PHK dari pihak pengusaha. Pendaftaran gugatan harus disertai dengan laporan penyelesaian perselisihan melalui mekanisme mediasi. Pengadilan Hubungan Industrial adalah pengadilan tingkat pertama, tetapi bukanlah tingkat terakhir, karena masih bisa dilakukan upaya hukum kasasi di Mahkamah Agung.

\section{Penutup}

\section{A. Kesimpulan}

1. Ketentuan Hak Pekerja Atas Pemutusan Hubungan Kerja Dengan Alasan Pandemi Covid-19 Setelah Disahkannya Undang-Undang No. 11 Tahun 2020 Tentang Cipta Kerja

Undang-Undang Cipta Kerja telah membuat cukup banyak perubahan terhadap Undang-Undang Ketenagakerjaan, khususnya dalam hal ini adalah yang menyangkut hak pekerja atas PHK dengan alasan pandemi Covid-19. Seperti yang diketahui, Undang-Undang Cipta Kerja menghapus Pasal 161169 Undang-Undang Ketenagakerjaan mengenai pengaturan khusus besaran nilai pesangon dan hak lainnya atas berbagai alasan dasar PHK. Hal ini menghapus perbedaan mengenai besaran nilai hak pekerja ter-PHK atas berbagai alasan yang sebelumnya diatur dalam Undang-Undang Ketenagakerjaan, sehingga hak pekerja ter-PHK dengan apa pun alasannya akan memiliki mekanisme penghitungan yang sama, tergantung dengan lamanya masa kerja. Namun, tidak ada perubahan mengenai besaran hak pekerja tidak tetap/PKWT yang di-PHK atas alasan pandemi Covid-19. Di samping itu, Undang-Undang Cipta Kerja juga melakukan penambahan program jaminan sosial baru, yaitu Jaminan Kehilangan Pekerjaan. Nantinya, pekerja ter-PHK yang terdaftar sebagai peserta Jaminan Kehilangan Pekerjaan yang ter-PHK akan memperoleh manfaat berupa uang tunai, akses terbuka atas informasi pasar kerja, dan juga beberapa pelatihan kerja yang dapat diikuti. 
2. Jenis pelindungan hak pekerja atas pemutusan hubungan kerja dengan alasan pandemi Covid-19 dalam Undang-Undang No. 11 Tahun 2020 Tentang Cipta Kerja

Undang-Undang Cipta Kerja turut meningkatkan pelindungan terhadap hak pekerja ter-PHK, tidak luput PHK yang berlandaskan alasan pandemi Covid-19. Pelindungan yang diberikan, yaitu penjatuhan sanksi pidana bagi pengusaha yang tidak melaksanakan kewajiban membayarkan pesangon, dan hak-hak pekerja lainnya sesuai dengan ketetapan Undang-Undang. Ada juga sanksi administratif kepada pengusaha yang tidak membayarkan uang kompensasi kepada pekerja tidak tetap/PKWT yang ter-PHK. Hal ini merupakan bentuk progresivitas hukum melihat perkembangan di dunia nyata yang menunjukkan masih banyak terjadi penyimpangan terhadap peraturan. Di samping itu, Undang-Undang Cipta Kerja tetap menjamin pekerja ter-PHK untuk bisa menuntut hak-haknya melalui pengajuan gugatan ke Pengadilan Hubungan Industrial, apabila pengusaha tidak menjalankan ketentuan Undang-Undang Cipta Kerja.

\section{B. Saran}

Penulis memiliki beberapa masukan yang disampaikan kepada pihak pengusaha, pekerja, dan aparat penegak hukum. Kepada pengusaha, ketentuan baru dalam Undang-Undang No. 11 Tahun 2020 Tentang Cipta Kerja ini sudah disesuaikan dengan keadaan beberapa tahun ke belakang yang menggambarkan bahwa ketentuan dalam Undang-Undang terdahulu tidak dapat dimaksimalkan dalam penerapannya. Maka dari itu, penulis harap pengusaha lebih mematuhi aturan ini demi terciptanya tujuan hukum dan kesejahteraan sosial.

Kepada pekerja, harapan penulis dengan adanya perubahan ini, yaitu pekerja mampu meningkatkan kesadaran akan hak-haknya yang dilindungi Undang-Undang, sehingga pekerja memiliki kemauan untuk menuntut apabila ada ketidaksesuaian dalam hal pemenuhan haknya.

Kepada aparat penegak hukum, diharapkan mampu menjunjung tinggi keadilan dalam memproses perkara pemenuhan hak pekerja yang ter-PHK demi tegaknya hukum itu sendiri. 


\section{Daftar Pustaka}

Ali, A. (2009). Menguak Teori Hukum dan Teori Peradilan. Jakarta: Kencana Prenada Media Group.

Ali, Z. (2017). Metode Penelitian Hukum. Jakarta: Sinar Grafika.

Asri, D. P. B. (2018). Perlindungan Hukum Preventif Terhadap Ekspresi Budaya Tradisional Di Daerah Istimewa Yogyakarta Berdasarkan Undang-Undang Nomor 28 Tahun 2014 Tentang Hak Cipta. Journal of Intellectual Property, 1(1). https://doi.org/10.20885/jipro.vol1.iss1.art2

Badan Pusat Statistik. (2020). Tingkat Pengangguran Terbuka (TPT) sebesar 4,99 persen. Diambil 20 Desember 2020, dari Badan Pusat StatisiK website: https://www.bps.go.id/pressrelease/2020/05/05/1672/februari2020--tingkat-pengangguran-terbuka--tpt--sebesar-4-99-persen.html

Disantara, F. P. (2020). Tanggung Jawab Negara Dalam Masa Pandemi Covid19. Jurnal Cendikia Hukum, 6(1). https://doi.org/10.33760/jch.v6i1.262 Juaningsih, I. N. (2020). Analisis Kebijakan PHK Bagi Para Pekerja Pada Masa Pandemi Covid-19 di Indonesia. Jurnal Adalah: Buletin Hukum dan Keadilan, 4(1). https://doi.org/10.15408/adalah.v4i1.15764

Karunia, A. M. (2020). Menaker: Hanya 7 Persen Perusahaan yang Mampu Bayar Pesangon 32 Kali Gaji. Diambil 16 Desember 2020, dari Kompas website: https://money.kompas.com/read/2020/10/14/195400326/ menaker-hanya-7-persen-perusahaan-yang-mampu-bayar-pesangon-32kali-gaji?page $=$ all

Kurniati, D. (2020). Kadin: 6,4 Juta Pekerja Dirumahkan atau Di-PHK Akibat Corona. Diambil 15 Desember 2020, dari News DDTC website: https://news.ddtc.co.id/kadin-64-juta-pekerja-dirumahkan-atau-di-phkakibat corona- 24551

Malau, Z. (2013). Perlindungan Hukum Pekerja/Buruh Atas Keselamatan Dan Kesehatan Kerja. Jakarta: PT Sofmedia.

Moeljatno. (2014). Kitab Undang-Undang Hukum Pidana. Jakarta: Bumi Aksara.

Nugroho, R. S. (2020). Ini Alasan WHO Memberi Nama Resmi Covid-19 untuk 
Virus Corona. Diambil 28 Desember 2020, dari Kompas website: https://www.kompas.com/tren/read/2020/02/12/063200865/ini-alasanwho-memberi-nama-resmi-covid-19-untuk-virus-corona?page =all

Pokrol, S. (2003). Keadaan Memaksa / Force Majeur.

Puluhulawa, J., Towadi, M., \& Swarianata, V. (2020). Perlindungan Hukum Situs Bawah Air Leato / Japanese Cargo Wreck. Reformasi Hukum, XXIV(2). https://doi.org/10.46257/jrh.v24i2.137

Rahardjo, S. (2000). Ilmu Hukum. Bandung: PT Citra Adtya Bakti.

Randi, Y. (2020). Pandemi Corona Sebagai Alasan Pemutusan Hubungan Kerja Pekerja Oleh Perusahaan Dikaitkan Dengan Undang-Undang Ketenagakerjaan. Jurnal Yurispruden, $3(2)$. https://doi.org/10.33474/yur.v3i2.6709

Republik Indonesia. Keputusan Menteri Kesehatan Republik Indonesia Nomor Hk.01.07/Menkes/413/2020 Tentang Pedoman Pencegahan Dan Pengendalian Coronavirus Disease 2019 (Covid-19).

Republik Indonesia. Keputusan Presiden Nomor 12 Tahun 2020 Tentang Penetapan Bencana Nonalam Penyebaran Coronavirus Disease 2019 (Covid-19).

Republik Indonesia. Undang-Undang Dasar Negara Republik Indonesia 1945. Republik Indonesia. Undang-Undang Nomor 11 Tahun 2020 Tentang Cipta Kerja.

Republik Indonesia. Undang-Undang Nomor 13 Tahun 2003 tentang Ketenagakerjaan.

Republik Indonesia. Undang-Undang Nomor 2 Tahun 2004 Tentang Penyelesaian Perselisihan Hubungan Industrial.

Republik Indonesia. Undang-Undang Nomor 40 Tahun 2004 Tentang Sistem Jaminan Sosial.

Simanjuntak, D. D. H. (2012). PHK dan Pesangon Karyawan. Yogyakarta: MedPress Digital.

Sunggono, B. (2018). Metodologi Penelitian Hukum. Jakarta: PT Raja Grafindo Persada. 
Suwantari, I. G. A. D., \& Astariyani, N. L. G. (2020). Perlindungan Hukum Terhadap Para Pekerja Yang Mengalami Pemutusan Hubungan Kerja Karena Dampak Digitalisasi. Jurnal Kertha Samaya, 6(7). Diambil dari https://ojs.unud.ac.id/index.php/kerthasemaya/article/view/53864

Yuniar, R. . (2020). May Day 2020: Buruh Yang Dipecat Saat Pandemi Virus Corona, Tidak Dapat Pesangon, Tabungan "Habis Sudah.” Diambil 16 Desember 2020, dari BBC website: https://www.bbc.com/indonesia/indonesia-52488832 